\title{
IMPACT OF IMPLEMENTED INNOVATIONS ON COMPETITIVENESS OF TOURISM COMPANIES IN THE WARMIŃSKO-MAZURSKIE VOIVODESHIP
}

\author{
Roman Kisiel ${ }^{\bowtie}$, Aleksandra Kowalewska, Joanna Kowalewska \\ University of Warmia and Mazury in Olsztyn, Poland
}

\begin{abstract}
The growing demand for tourism services has led to the establishment and development of many companies in the hospitality industry, which are driven by a need to stand out in the market and acquire new clients. To do this, they make efforts to improve their competitiveness by implementing specific innovations in hopes of strengthening their market position. The aim of this paper is to discuss the effect of innovations on the competitiveness of tourism and hospitality enterprises, using chosen companies from the Warmińsko-Mazurskie Voivodeship in Poland as a case study. The empirical part of the research consisted of one questionnaire addressed to the clients and the other one addressed to the employees and owners. Both questionnaires were conducted in three companies. The results of these surveys provided information which indicated that the most important assets that allowed companies to distinguish themselves on the market were the innovations that they implemented. In addition, over half of the employees in these companies declared that innovations had contributed to an increase in the number of customers.
\end{abstract}

Key words: tourism company, innovativeness, competitive position, competitive advantage, Warmińsko-Mazurskie Voivodeship

JEL codes: $\mathrm{L} 83, \mathrm{O} 31, \mathrm{O} 32$

\section{INTRODUCTION}

Growing competition in the tourism services market forces companies to make efforts to attract new customers for their services and to retain their loyal customers. Most often, tourists take advantage of a variety of services offered by companies in the hospitality sector, including catering or accommodation [Rapacz 1994]. It may be possible to appeal to increasingly more demanding customers by implementing innovations, which are indicated as a factor with positive influence on the competitive capabilities of companies. Competitive capabilities arise from a company's innovative approach as well as effective performance, entrepreneurship, flexibility and the ability to adjust to dynamic changes in the environment or the ability to gain an advantage in the market owing to innovations [Bossak and Bieniowski 2004].

Poland is a country with many tourist attractions, not only cultural but also natural [Ozimek et al. 2019]. Therefore, there are numerous tourism enterprises which compete with each other. Successfully implemented innovative solutions are an opportunity that seems particularly promising to tourism companies in the Warmińsko-Mazurskie Voivodeship. Tourism enterprises play a significant role in the hospitality business, which is among the most developed business sectors in this province, although the performance of 
tourism companies in this region largely depends on the profits gained in the summer, which - because of local climate conditions - is the most important but relatively short high season. The innovativeness of business enterprises attracts more interest among clients, who are then more willing to benefit from services that are also offered outside the high season. The question of innovations in the hospitality business is raised more and more often, being perceived as the future of all companies, which must adjust to a rapidly changing, competitive world. An example of a sudden change is the outbreak of the COVID-19 pandemic, when businesses involved in tourism needed to distinguish themselves in very unique ways to attract potential clients.

The purpose of this article is to discuss the effects of implemented innovations on the competitiveness of tourism companies in the Warmińsko-Mazurskie Voivodeship, based on a case study of the companies included in our research poll. The results allowed us to identify dependences between implemented innovations in tourism companies and their capabilities of operating and competing in a competitive market

\section{METHODOLOGY}

The research consisted of a theoretical and an empirical part. The theoretical part was developed on the basis of the available Polish and foreign subject literature. The empirical part contains results of two questionnaires: one addressed to clients (containing 13 questions) and the other to employees and owners of tourism companies (containing 12 questions). The questionnaires were composed of two different sets of questions: clients were asked how they perceived tourism companies from the point of view of someone outside these businesses, and employees and owners of such companies received a questionnaire with questions that required some experience in the hospitality sector, also including some detailed information about the given company and the entire sector. Three tourism companies operating in the Warmińsko-Mazurskie Voivodeship, which had implemented some innovations, were selected for the study. These were:

1. Strefa Przygody (where the questionnaire was returned by 44 clients and 6 employees).
2. Glendoria (where 42 clients and 8 employees answered the questionnaire).

3. Szarpie Travel (the questionnaire concerned the recreational centre called Kulka, and was returned by 30 clients, 19 employees and 1 co-owner).

The questionnaires, which were completed during the tourist season (i.e. August, September, October) of 2019 , were delivered by the authors to companies as printouts and were filled in by a total of 150 persons, that is 50 respondents in each of the chosen locations. The respondents were a randomly chosen group from all clients and employees who consented to participating in the research.

The questionnaires were designed so as to ensure the effectiveness of the study; they were confidential, brief, clearly worded and had few "yes/no" questions [Majchrzak and Mendel 1999]. In addition to this, the questionnaires provided data on the person who carried out the survey and the survey purpose [Sołoma 1999]. Most questions were close-ended (10 of the 13 questions in the questionnaire addressed to clients, 10 out of 12 questions addressed to employees and owners of the companies), with multiple- and single-choice answers, concerning such issues as the indication of the most attractive characteristics of the company in question according to its clients, or the effects of implemented innovations on the competitiveness of this company. Employees and owners were asked about the impact of innovations on the number of new customers or about plans to implement new solutions in the following two years, with a view to increasing the company's innovativeness. The results are presented in graphs, tables and descriptively.

\section{INNOVATIONS AS A FACTOR OF INCREASING THE COMPETITIVENESS OF TOURISM COMPANIES}

More and more businesses, including tourism companies, as a result of the widespread access to products and services on a mass scale, are forced to improve the attractiveness of their offers and to make themselves distinguished in the market [Kisiel et al. 2018]. The key contributors to the growth in competitiveness include innovations as well as the ability to consistently implement such innovations. Skillful implementation of innovative solutions is extremely important as the 
only constant thing in the modern economy is constant change [Gunday et al. 2011].

Unique, cutting-edge solutions must be sought by companies in any branch of industry, so as to reinforce their model of performance and to increase the share in the market via innovation [Kisiel et al. 2017]. Therefore, innovation is believed to be a principal factor which decides an enterprises' competitive position in the twenty-first century [Gryszel et al. 2010]. This is particularly important in tourism and hospitality, where the acquisition of clients depends strongly on the offer proposed by tourism companies. Innovations attract the attention of tourists and may represent the key factor in deciding to select a given company over others [Kryk and Piech 2009].

The word "innovation" descends from the Latin innovatio which means to form something new [Peters and Pikkemaat 2006]. Innovation is believed to be a way of creative thinking and implementing ideas, it is altering advanced notions and knowledge into unique and newly created solutions. Therefore, innovativeness is often considered to be essential in building enterprises' competitive advantage [Roman et al. 2020].

Because different scientific disciplines suggest different definitions of innovation, it is difficult to phrase a precise definition thereof. R.W. Griffin faced this challenge and juxtaposed mutually excluding types of innovations. As a result, the following division was proposed [Georgescu-Roegen 1976]:

1. Radical innovations (these are newly developed technologies, products and services, the aim of which is to replace existing solutions) and gradual innovations (i.e. modifications to existing products, services or technologies).

2. Technological innovations (changes in the design of a product, service or production process) and management innovations (modifications in the management process regarding the planning, creating and distributing of goods and services).

3. Product innovations (rarely concerning the development of a new product or services, they more often entail changes in the biological, physical or chemical properties of existing products and services) and process innovations (i.e. implementation or improvement of existing production processes or services).
Tourism companies that wish to be competitive - to perform and compete well in a competitive environment in order to develop, gain benefits and profits, and secure a competitive advantage - are increasingly more willing to implement innovations [Gorynia 2002].

\section{RESULTS OF THE STUDY}

Three tourism companies operating in the Warmińsko-Mazurskie Voivodeship were selected for the study. Clients (in total 116 persons, i.e. $77.3 \%$ of the respondents) and owners and employees (34 persons, i.e. $22.7 \%$ of the respondents) completed the questionnaires, which provided data for research analysis.

One of these companies was Glendoria, situated in the village Ględy in the Ostróda District. The innovative solution of this company was to offer accommodation in tented rooms (so-called glamping, the merger of "glamour" and "camping"). Glendoria offers five tents, each in a different style, waterproof, protected against insects, and set on wooden floors. Guests are also offered a roofed veranda, hammocks and a woodfired stove. Another innovation implemented in Glendoria, a so-called Camp Spa, also attracts visitors. This is an open-air spa set in a pine forest, with timber buildings as well as a wooden bathtub, all ensuring close contact with nature. What makes the Camp Spa unique is that rather than being a single building, it is a complex of facilities and each treatment (e.g. a massage) is carried out in another part of the forest.

Another innovative company selected for the study was the travel agency Szarpie Travel, which offers holidays and camps for school pupils all around Poland, although the questionnaire pertained to the services offered at Kulka, which is the holiday resort owned by Szarpie Travel. It is situated in the Dźwierzuty Municipality, Szczytno District. The Kulka holiday resort is a pioneer in innovative solutions that ensure a variety of forms of relaxation for children, with unique types of activities using such modern equipment as dragon boats, Segway scooters and gyroscopes (e.g. a space flight simulator). Other unique attractions which allow children to spend their time actively on land, water or in the air are the so-called bambonada (DIY large size interlocking building sticks for making big 
constructs), zorbing (rolling in a large plastic orb), quilling (creating 3-D art using special techniques and materials) or riding quads. All these original solutions, as well as a wide range of offered products such as green schools, camps or holidays for children, including "Little Cadet Adventures", "Space Wars", "Hero Camp" or "Four Elements", have become a trademark of the Szarpie Travel and Kulka holiday resort.

The third company included in the study was Strefa Przygody (which literally means "adventure zone") with has its office in Olsztyn. It organizes green schools, holidays, camps, events and parties for children with party entertainers (for example on St. Nicolas Day). The innovation implemented by the Strefa Przygody consists of their own programme of skill badges - unique badges which participants of camps, holidays or green schools can earn by performing special tasks. A child wins an award for earning all the badges (including "Rider", "Strategist", "Bowling Champion", etc.). The aim is to encourage participants to gain new knowledge and skills, on each occasion ensuring the most joy from using the company's services.

From the answers given in the questionnaires, it is apparent that respondents differed in their opinions about the extent to which the innovations influenced any increase in company competitiveness (Table 1). $44.8 \%$ concluded that innovations contributed substantially to growth in the competitiveness of the analysed companies. The frequency at which this reply was chosen suggests that more and more people pay attention to the uniqueness of an offer, which may be the key to building a competitive advantage that will have an impact on a company's revenues. Higher competitiveness owing to innovations in the three companies was indicated by $33.6 \%$ of respondents, while
$16.4 \%$ answered that such improved competitiveness was likely. $5.2 \%$ decided it was difficult to identify the dependence between the company's competitiveness and its innovative offer, which is why they chose the answer "impossible to say".

The questionnaire also asked clients to point out the three most attractive features of the company whose services they used. In Glendoria, these were the idea of glamping (32 persons), closeness to nature (30 persons) and Camp Spa ( 28 persons). The fact that the company's innovative solutions were most often given in the answer to this question (unlike, for example, an opportunity to spend one's free time actively, which was selected by just 2 persons) justifies the conclusion that atypical solutions are appreciated by tourists, and that they create an appealing image of the company in the eyes of clients. The innovations in the two other companies were also most often indicated as their assets. Thus, Kulka holiday resort (owned by Szarpie Travel) was appreciated by tourists because of unique forms of active relaxation (e.g. the space flight simulator), a diverse offer (e.g. green schools) and modern, innovative equipment. Strefa Przygody was mostly appreciated for Strefa Przygody badges, and for the holiday planner application, which enables clients to tailor a stay according to their expectations. These two assets were chosen by 19 and 17 respondents, respectively, who used the services of this company.

The questionnaire addressed to clients also contained a question of whether the company whose services they used was worth recommending. Out of 116 clients, nobody marked the answer suggesting the company should not be recommended (Table 2). Positive opinions reflect the satisfaction achieved by clients using the services of Glendoria, Szarpie Travel (in

Table 1. Effect of the innovative character of the analysed companies on their competitiveness

\begin{tabular}{lc}
\hline Answers given & Results (\%) \\
\hline Difficult to say & 5.2 \\
\hline Probably an increase in competitiveness & 16.4 \\
\hline Increase in competitiveness & 33.6 \\
\hline Definitely an increase in competitiveness & 44.8 \\
\hline
\end{tabular}

Source: Authors' elaboration based on own research poll. 
Kisiel, R., Kowalewska, A., Kowalewska, J. (2020). Impact of implemented innovations on competitiveness of tourism companies in the Warmińsko-Mazurskie Voivodeship. Acta Sci. Pol. Oeconomia 19 (4), 87-94, DOI: 10.22630/ASPE.2020.19.4.44

Table 2. Answers of respondents on whether the company in question is worth recommending

\begin{tabular}{lc}
\hline The company is worth recommending because: & Results (\%) \\
\hline it has a unique and innovative offer & 45.7 \\
\hline quality to price ratio for services offered is positive & 21.6 \\
\hline services offered by the company meet expectations & 21.6 \\
\hline owners/staff are experienced and helpful & 11.2 \\
\hline
\end{tabular}

Source: Authors' elaboration based on own research poll.

Kulka) or Strefa Przygody. Despite a general agreement that the companies were worth recommending, the justifications to this reply were varied. Nearly $50 \%$ of respondents indicated the unique and innovative offer, which leads to the conclusion that innovations build a positive image of a company, owing to which business enterprises can attract new clients and improve their competitiveness. However, two other popular answers (indicated by $21.6 \%$ of the respondents, each) were the positive quality to price ratio regarding the services offered, and the fulfilment of customers' expectations. The least stated answer was the experience with the owners and employees of the company, and their helpful attitude (this justification was selected by $11.2 \%$ of respondents).

The clients, who represented $77.3 \%$ of the total number of respondents, were asked to evaluate the companies Glendoria, Szarpie Travel and Strefa Przygody relative to other tourism companies which they have used. This was an open-ended question and many persons (32.8\%) declined to answer it, probably because of the time it required to write the answers. However, the answers which were given were dominated by opinions about the outstanding position of the evaluated companies, owing to high quality and innovative offers. The clients also appreciated the location, helpful staff, personal approach and the service quality to price ratio. It is therefore evident that the tourists had a positive opinion about the companies they evaluated against the backdrop of other businesses in the hospitality sector, not only because of the prices and location, which for years have been pivotal to selecting service providers in the tourism market, but also because of the implemented innovations and the fact that the companies in question were able to create interesting and unique offers.

The second questionnaire was addressed to owners and employees of the three analysed companies. One of the questions was whether they noticed a change in the number of clients after implementing some innovations in their companies (Fig. 1). Well over half of the respondents $(67.8 \%)$ agreed that innovations

Fig. 1. Effect of implemented innovations on the number of company clients

Source: Authors' elaboration based on own research poll.

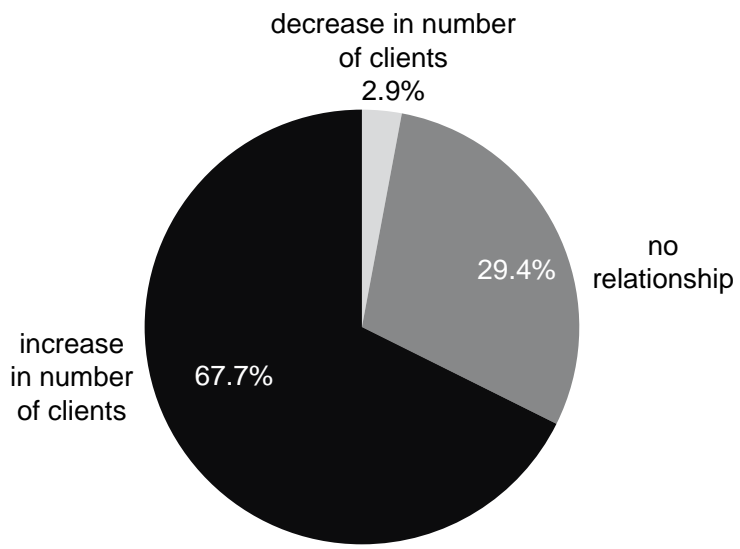


contributed to attracting more customers to Glendoria, Szarpie Travel or Strefa Przygody. Only one person (i.e. $2.9 \%$ ) responded that innovations caused a decrease in the number of clients. In light of the replies, it can be concluded that the companies were able to improve their competitiveness by implementing certain innovations, as this gave them a more attractive offer and stood out among other companies operating in the hospitality business, in addition to which they could attract new clients and earn higher profits.

An example illustrating the important role played by innovations in creating the image of a company could be the fact that 22 persons employed in the three analysed companies pointed to the original and up-to-date solutions as being of special value to clients because such innovations, in their opinion, are among the essential attributes of tourism companies. Nevertheless, four of the employees claimed they were unaware of such opinions, and eight respondents did not say whether innovations could be considered more interesting by clients because the nature of their work does not involve direct contact with clients (Fig. 2).

Over $44 \%$ of the employees declared that the companies they work for plans to take new measures aimed at increasing the innovativeness of their enterprise (Fig. 3). Over half of the respondents (52.9\%) admitted they lacked sufficient knowledge to answer this question, while just one person (i.e. $2.9 \%$ ) stated that the company would not seek to improve its competitiveness by implementing innovative solutions in the nearest future.

The intention of the companies to further invest in innovations reflects the belief held by the owners of the selected businesses that modern solutions, despite relatively high costs of their implementation, will not only offset these costs over time but will also generate higher revenues and will create opportunities for the company to grow.

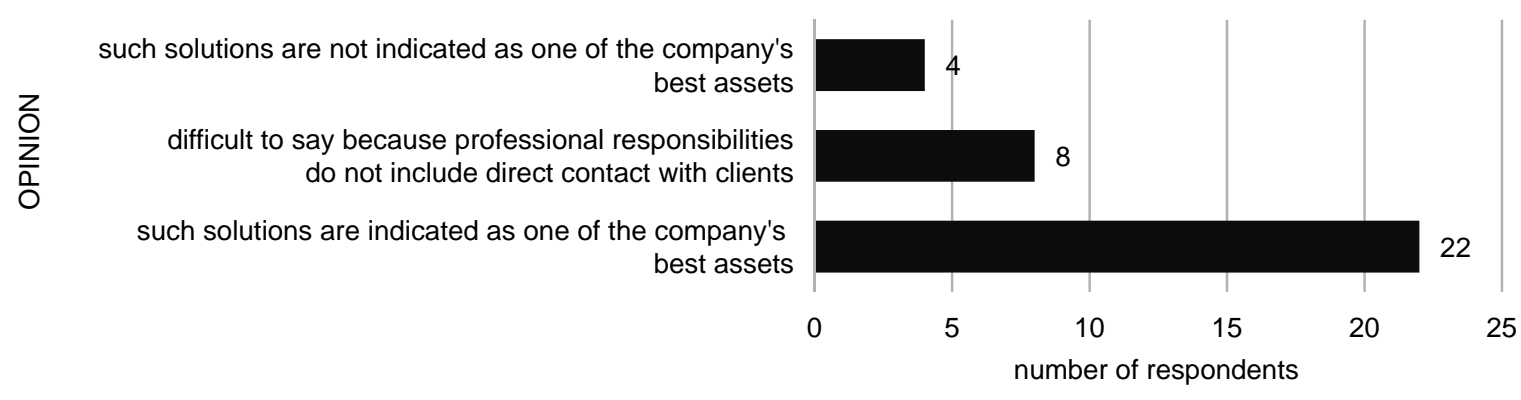

Fig. 2. Opinions of clients about unique and modern solutions implemented in the company according to employees and owners

Source: Authors' elaboration based on own research poll.

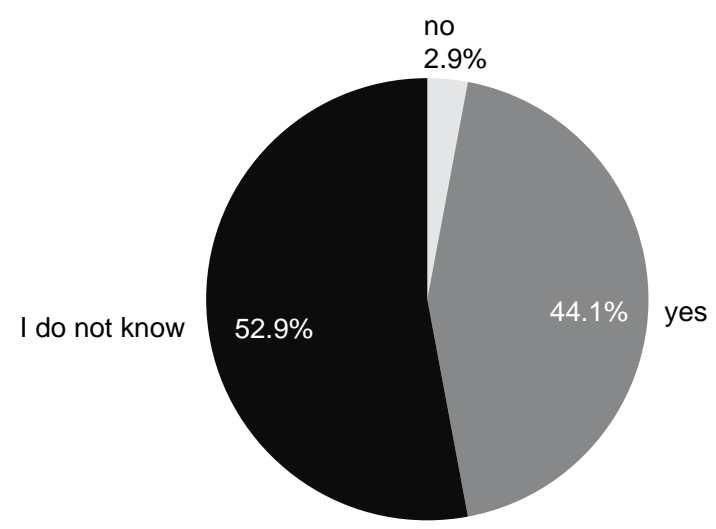

Fig. 3. Plans of the company to take measures in the following two years in order to improve its innovativeness

Source: Authors' elaboration based on own research poll. 


\section{SUMMARY}

Tourism companies, especially ones which operate in areas with a limited high season, like the Warmińsko-Mazurskie Voivodeship, gain an opportunity for planned development by successfully implementing innovations based on their understanding and meeting of tourist expectations. Moreover, the consistent and innovative development of a company can lead to its building a competitive advantage or gaining a competitive position in the market.

\section{CONCLUSIONS}

The research presented in this paper aimed to present the effect of innovations on the competitiveness of tourism companies and to learn opinions of clients, employees and owners of selected tourism companies that had implemented some innovative solutions while operating in the hospitality sector. The study involved 150 respondents, $77.3 \%$ of whom were clients and $22.7 \%$ were employees and owners of tourism companies.

Answers to the questionnaires and their detailed analysis led to the following conclusions:

1. Tourists are aware that the implemented innovations enable tourism companies to gain new clients and to adapt well to changes in their environment, which is evidenced by the fact that $44.8 \%$ of the respondents decided that the innovative character of the three companies in the study "definitely contributed" to an increase in their competitiveness. Moreover, as many as $33.6 \%$ of the respondents said that such innovative solutions "contributed" to the growing competitiveness of these companies.

2. Clients were asked to identify up to three of the most appealing characteristics of the company whose services they had used. The answers justified the conclusion that the innovations implemented in the companies were particularly appreciated by the respondents, as all three companies, i.e. Glendoria, Szarpie Travel and Strefa Przygody, were most often appreciated for their innovative solutions.

3. All 116 clients declared that they had been satisfied with the offer of the company they had used and would recommend this company to others. The positive opinions were mostly $(46.7 \%)$ based on the innovative offer that distinguished the company from others. In turn, $21.6 \%$ of the respondents attributed their positive opinion to the fact that the company had met their expectations regarding the services offered. Moreover, the same percentage $(21.6 \%)$ of clients pointed to the positive quality to price ratio. The competitiveness of the analysed companies is further confirmed by the fact that many of their clients were willing to recommend them to others.

4. The answers given to the questionnaire addressed to employees and owners of tourism companies show that $67.8 \%$ of the respondents are of the opinion that the innovations their companies had implemented resulted in increasing numbers of clients. This finding justifies the conclusion that innovative solutions not only attract new clients but also enable companies to earn higher profits.

5. The three innovative tourism companies selected for this study have plans to take measures within the following two years in order to improve their innovativeness. This option was selected by $44.1 \%$ of employees and owners, who justified their answer by the company's drive to attract new clients or to maintain its satisfying position in the increasingly competitive business sector. This is proof of the important role of innovation in the operation of tourism companies.

The results obtained in this study demonstrate that implementation of innovations is an opportunity for companies to stand out in the tourism market. However, it is recommended to introduce innovative solutions that will correspond well to the needs of clients of a given company and that will satisfy their expectations. In the current situation of the COVID-10 pandemic, innovations can be a key to attracting tourists, who are now much more careful in selecting destinations for their travel.

\section{REFERENCES}

Bossak, J., Bieniowski, W. (2004). Międzynarodowa zdolność konkurencyjna kraju i przedsiębiorstw. Wyzwania dla Polski na progu XXI wieku. Oficyna Wydawnicza SGH, Warszawa. 
Georgescu-Roegen, N. (1976). Energy and Economic Myths. Southern Economic Journal, 41 (3), 347-381.

Gorynia, M. (2002). Luka konkurencyjna na poziomie przedsiębiorstwa a przystapienie Polski do Unii Europejskiej. Wydawnictwo Akademii Ekonomicznej w Poznaniu, Poznań.

Gryszel, P., Jaremen, D., Rapacz, A. (2010). Innovation of tourism enterprises based on the example of Karpacz. Acta Scientiarum Polonorum. Oeconomia, 9 (4), $143-152$.

Gunday, G., Ulusoy, G., Kilic, K., Alpkan, L. (2011). Effects of Innovation Types on Firm Performance. International Journal of Production Economics, 133, 662-676.

Kisiel, R., Zielińska-Szczepkowska, J., Mówińska, K. (2017). Inicjatywa JEREMIE jako źródło wsparcia i rozwoju konkurencyjności sektora małych i średnich przedsiębiorstw. Studium przypadku województwa zachodniopomorskiego. Wydawnictwo Uniwersytetu Warmińsko-Mazurskiego, Olsztyn.

Kisiel, R., Zielińska-Szczepkowska, J., Taradejna, D. (2018). Natural and cultural resources of Green Kurpie as drivers of tourism development. Ekonomia i Środowisko, 2, 231-245.
Kryk, B., Piech, K. (Eds.) (2009). Innowacyjność w skali makro i mikro. Instytut Wiedzy i Innowacji, Warszawa.

Majchrzak, J., Mendel, T. (1999). Metodyka pisania prac magisterskich i dyplomowych. Poradnik pisania prac promocyjnych oraz innych opracowań naukowych wraz z przygotowaniem ich do obrony lub publikacji. Akademia Ekonomiczna w Poznaniu, Poznań.

Ozimek, I., Gralak, K., Pomianek, I. (2019). Atrakcyjność turystyczna województw w Polsce - wybrane aspekty. Wydawnictwo SGGW, Warszawa.

Peters, M., Pikkemaat, B. (2006). Innovation in Tourism. Journal of Quality Assurance in Hospitality \& Tourism, 6 (3-4), 1-6.

Rapacz, A. (1994). Przedsiębiorstwo turystyczne. Podstawy i zasady działania. Wydawnictwo Naukowe PWN, Warszawa.

Roman, M., Roman, M., Prus, P. (2020). Innovations in Agritourism: Evidence from a Region in Poland. Sustainability, 12 (12), 4858, https://doi.org/10.3390/ su12124858

Sołoma, L. (1999). Metody i techniki badań socjologicznych. Wybrane zagadnienia. Wyższa Szkoła Pedagogiczna, Olsztyn.

\section{WPŁYW WDROŻONYCH INNOWACJI NA KONKURENCYJNOŚĆ PRZEDSIĘBIORSTW TURYSTYCZNYCH W WOJEWÓDZTWIE WARMIŃSKO-MAZURSKIM}

\section{STRESZCZENIE}

Rosnący popyt na usługi turystyczne przyczynił się do powstania oraz rozwinięcia się wielu przedsiębiorstw turystycznych, które dążąc do wyróżnienia swojej oferty na rynku oraz pozyskiwania nowych klientów, podejmują działania mające na celu zwiększenie swojej konkurencyjności. Skutecznym rozwiązaniem jest wdrażanie innowacji w przedsiębiorstwach, dzięki którym mogą umocnić swoją pozycję. Celem pracy jest przedstawienie wpływu innowacji na konkurencyjność przedsiębiorstw turystycznych na przykładzie wybranych podmiotów działających na terenie województwa warmińsko-mazurskiego, w związku z czym w trzech przedsiębiorstwach przeprowadzona została ankieta skierowana do klientów oraz ankieta skierowana do pracowników i właścicieli. Ich wyniki pozwoliły uzyskać informacje, zgodnie z którymi m.in. największymi atutami, dzięki którym badane podmioty pozytywnie odznaczały się na rynku, były innowacje. Ponadto więcej niż połowa zatrudnionych oznajmiła, iż innowacje przyczyniły się do wzrostu liczby klientów.

Słowa kluczowe: przedsiębiorstwo turystyczne, innowacyjność, pozycja konkurencyjna, przewaga konkurencyjna, województwo warmińsko-mazurskie 